\title{
Anthropogenic Biotic Interchange in a Coral Reef Ecosystem: A Case Study from Guam ${ }^{1}$
}

\author{
Gustav Paulay, ${ }^{2,3}$ Lisa Kirkendale, ${ }^{2,3}$ Gretchen Lambert, ${ }^{4}$ and Cbris Meyer ${ }^{2,3}$
}

\begin{abstract}
Guam is the administrative and economic hub of Micronesia, hosts one of the largest U.S. military bases in the Pacific, and lies at the crossroads among Pacific islands, the United States, and Asia. Although terrestrial introductions, exemplified by the brown tree snake, have received much attention, marine introductions have been little studied until now. We have documented a diverse assemblage of marine species brought to Guam by human-mediated transport: a few intentionally, most unintentionally. Sessile species dominate the nonindigenous biota. Because of Guam's tourism-based economy, ballast water is not a major source of introductions, but ship's hulls have brought many invaders. A study of the fauna associated with two dry docks demonstrates the large impact of such structures, moved slowly from harbor to harbor after long residence times. The majority of nonindigenous species have remained confined to artificial substrata in the harbor, but some have invaded adjacent coral reef habitats and spread islandwide. Although several nonindigenous species are now well established, major impacts to reefs on Guam remain to be identified. Space on reefs is vastly dominated by indigenous species; in contrast artificial substrata often have an abundance of nonindigenous species.
\end{abstract}

Coral REEFs ARE arguably the most diverse and among the most vulnerable shallowwater marine habitats. The faunal richness of reefs, like that of other highly diverse habitats, is still poorly documented, but appears to be at least in the many hundreds of thousands of species (Paulay and Meyer 2001,

${ }^{1}$ Paper presented at the Ninth International Coral Reef Symposium, Bali, Indonesia, 27 October 2000. Financial support provided by SeaGrant (SG-NIS-35), U.S. Department of Defense (COMNAVMARIANAS), Insular Pacific Regional Marine Research Program, and NSF (DEB-9807316); support for Lisa Kirkendale to attend the International Coral Reef Symposium was provided through the National Oceanic and Atmospheric Administration. Manuscript accepted 15 January 2002.

2 Marine Laboratory, University of Guam, Mangilao, Guam 96923.

${ }^{3}$ Florida Museum of Natural History, University of Florida, Gainesville, Florida 32611 (E-mail: paulay@ flmnh.ufl.edu).

${ }^{4}$ Friday Harbor Laboratories, University of Washington, Friday Harbor, Washington 98250.

Pacific Science (2002), vol. 56, no. 4:403-422

(C) 2002 by University of Hawai' $i$ Press

All rights reserved unpubl. data). The vulnerability of reefs to anthropogenic disturbances is being increasingly realized with the spread of coral bleaching, the emergence and spread of numerous diseases that affect major reef-building and reef-associated taxa, and the large-scale reef destruction that has resulted from a wide range of human activities (e.g., Wilkinson 2000, Jackson et al. 2001). How important are nonindigenous species as threats to reefs? Have many nonindigenous species invaded coral reef systems? Has their impact been great? The purpose of this study was to evaluate the nature and impact of the anthropogenic biotic interchange on coral reefs on a diverse and moderately disturbed reef site: the island of Guam.

Lying just east of the western Pacific diversity center, Guam hosts by far the most diverse reefs under U.S. jurisdiction. For example, the 276 species of reef coral species in the local fauna represent about four times the diversity of the entire Caribbean and more than five times the diversity of the Hawaiian reef coral faunas (Maragos 1995, Paulay 1997, Randall 2002). As the economic and population hub of Micronesia, the island also hosts 
the largest and busiest port in the area and thus has the greatest potential for receiving nonindigenous species.

Biotic interchange is frequently asymmetrical, with one region predominating as donor, the other as receiver of migrants (Vermeij 1991). The more diverse region is usually the donor, disproportionately biased relative to that predicted from its greater diversity alone. This has been interpreted as reflecting different levels of escalation among regional biotas-with more diverse biotas being at a higher level of escalation, and thus having a greater ability to invade, than less diverse biotas (Vermeij 1991). Although these hypotheses are based on examples of natural biotic interchange, they can be extended to predict anthropogenic biotic interchange as well. Thus high-diversity habitats such as reefs, especially near the global marine biodiversity center, may be expected to be relatively resistant to the invasion of nonindigenous species. This expectation is gaining some empirical support (Stachowicz et al. 1999). If so, nonindigenous species would be expected to establish only in limited, disturbed areas and to penetrate into undisturbed reef communities on a more limited basis. Guam, with highly diverse reef habitats combined with both long-term and largescale human influence, provides an excellent area to test these expectations.

\section{Regional Setting and Human Impact}

Guam $\left(13^{\circ} \mathrm{N}, 144^{\circ} \mathrm{E} ; 541 \mathrm{~km}^{2}\right)$, the southernmost island of the Mariana Archipelago, is the largest and economically most developed island in Micronesia, and the regional hub for shipping and travel. Guam has long been the center of regional activities. The Marianas were among the first islands settled in Micronesia, with clear evidence for human occupation dating to 3500 B.P. and indications of human presence to 4300 B.P. (Kirch 2000). Magellan's landing on Guam in 1521 was the first western contact in Oceania. Although virtually no other central Pacific island experienced appreciable European influence until the late eighteenth century, Guam became a major stop along the Manila-Acapulco gal- leon route starting in the sixteenth century and a Spanish colony in the seventeenth century. Guam became a U.S. territory after the Spanish-American War in 1898, and the rest of the Mariana Islands passed through first German, then Japanese hands at that time. The island has been affiliated with the United States ever since, except for a brief period of Japanese occupation during World War II. Economic activities, including shipping, increased substantially during World War II and have grown steadily since then. Today the economy depends strongly on tourism and on the U.S. military. With a population currently around 140,000 and with well over a million tourists a year, Guam is the most populous and visited island in the region. Thus, opportunities for the introduction of nonindigenous species within Micronesia have always been greatest in Guam.

Opportunities for introduction and the rate of influx of nonindigenous species into Guam have clearly increased through time. Documented introductions of terrestrial organisms dating from the prehistoric period include numerous cultivars, rats, lizards, land snails, and likely several insects and other invertebrates. Marine organisms may also have arrived with ancient voyaging canoes. During the Spanish period, galleons and other vessels provided avenues for the colonization of marine as well as terrestrial organisms (cf. Carlton and Hodder 1995). The military buildup during and after World War II has led to large-scale movement of personnel and materials, with increasing opportunities for introductions. The most infamous nonindigenous species from this period is the brown tree snake (Boiga irregularis), believed to have come from the Solomons or New Guinea with military cargo, which has spread rapidly through the island with devastating consequences for the terrestrial vertebrate, especially avian, fauna (Savidge 1987). In addition to unintentional introductions, many species were purposefully introduced on land and a few in the ocean. Introductions included a range of food plants and animals, ornamentals, and biocontrol agents (e.g., $\mathrm{Na}$ fus and Schreiner 1989, McConnell and Muniappan 1991). The extent and impact of 
terrestrial introductions have received some attention, but those in the marine environment have remained relatively little studied (but see Eldredge 1994).

\section{Geology and Reefs}

The Mariana Island arc is composed of young, active volcanic islands to the north and geologically more complex, volcanically quiescent, older islands to the south. The northern islands have volcanic shores with limited reef development, but much of the shoreline of the southern islands is karstic, composed of uplifted Pleistocene reefs surrounded by narrow benches, fringing reefs, and occasional barrier reefs. Guam has the best-developed reef system in the Marianas, including the only deep lagoon, Apra Harbor, which also functions as the main regional port (Figures 1, 2). Nevertheless, in comparison with islands in Palau and the Federated States of Micronesia to the south and the Marshall Islands to the east, the reefs and lagoons of the Marianas are considerably less developed.

The relatively limited reef development around Guam is reflected in a relatively narrow diversity of marine habitats. The development of fringing reefs ranges from absent, through narrow raised benches and intertidal flats, to more substantial fringing reefs with well-developed moats and barrier reefs. A striking north-to-south gradient in reef development appears to be partly the result of uneven tectonic uplift. Thus karstic, northern Guam has the narrowest reefs, and the volcanic south has the widest reefs. Reef development is also under local geological control, with the large embayments in Tumon, $\mathrm{Ha}$ gåtña, and Pago having developed the widest fringing reefs, and with a barrier reef developed north of the projecting Orote Peninsula. The last encloses Apra Harbor, the only deep lagoon on Guam. The only other barrier reef lies at the southern end of Guam, enclosing shallow ( $<12 \mathrm{~m}$ deep) Cocos Lagoon. Additional variation in reef habitat results from differences in wind, wave, and current exposure, with eastern reefs being more exposed than western reefs to both tradewinds and typhoons. Fore reefs exhibit moderate varia- tion around the island in width, terracing, and the abundance of mobile sediments. Mangroves are limited to very small stands in stream estuaries and to larger, but still narrow bands in inner Apra Harbor and at the southeastern end of the island in Merizo. Sea grass beds are developed along the larger fringing reef systems as well as in Cocos $\mathrm{La}$ goon.

\section{Apra Harbor}

Apra Harbor is the only deep lagoon in the Marianas; it is also the largest and busiest port in the archipelago. The unique environment of the harbor provides habitat for many species that are found nowhere else on Guam. The harbor is also the main point of entry for species introduced by shipping traffic. Both types of species are important from a conservation perspective: species restricted to the harbor are vulnerable to local extinction because of their restriction to a small area with high levels of human impact, and introduced species may negatively impact indigenous species. The restriction of many indigenous species to the harbor, however, also makes the identification of nonindigenous species on Guam more difficult.

Apra Harbor has been substantially altered from its original form since World War II. The lagoon was originally bounded by the Orote Peninsula along the south, the bulk of Guam along the east, and Cabras Island along the northeast. The northern perimeter of the lagoon was protected by Luminao barrier reef, giving way to Calalan Bank, a submerged barrier reef lying at a mean depth of ca. $6 \mathrm{~m}$, farther westward. Glass Breakwater, constructed atop Luminao Reef and Calalan Bank after World War II, led to the complete enclosure of Apra Harbor along the north. This structure greatly reduced circulation between the harbor and the ocean by restricting exchange to the western harbor entrance (Figure 2).

In addition to these alterations to the Apra barrier reef system, filling and dredging altered the inner parts of the harbor after World War II. Most important among these changes were (1) the dredging of the inner 


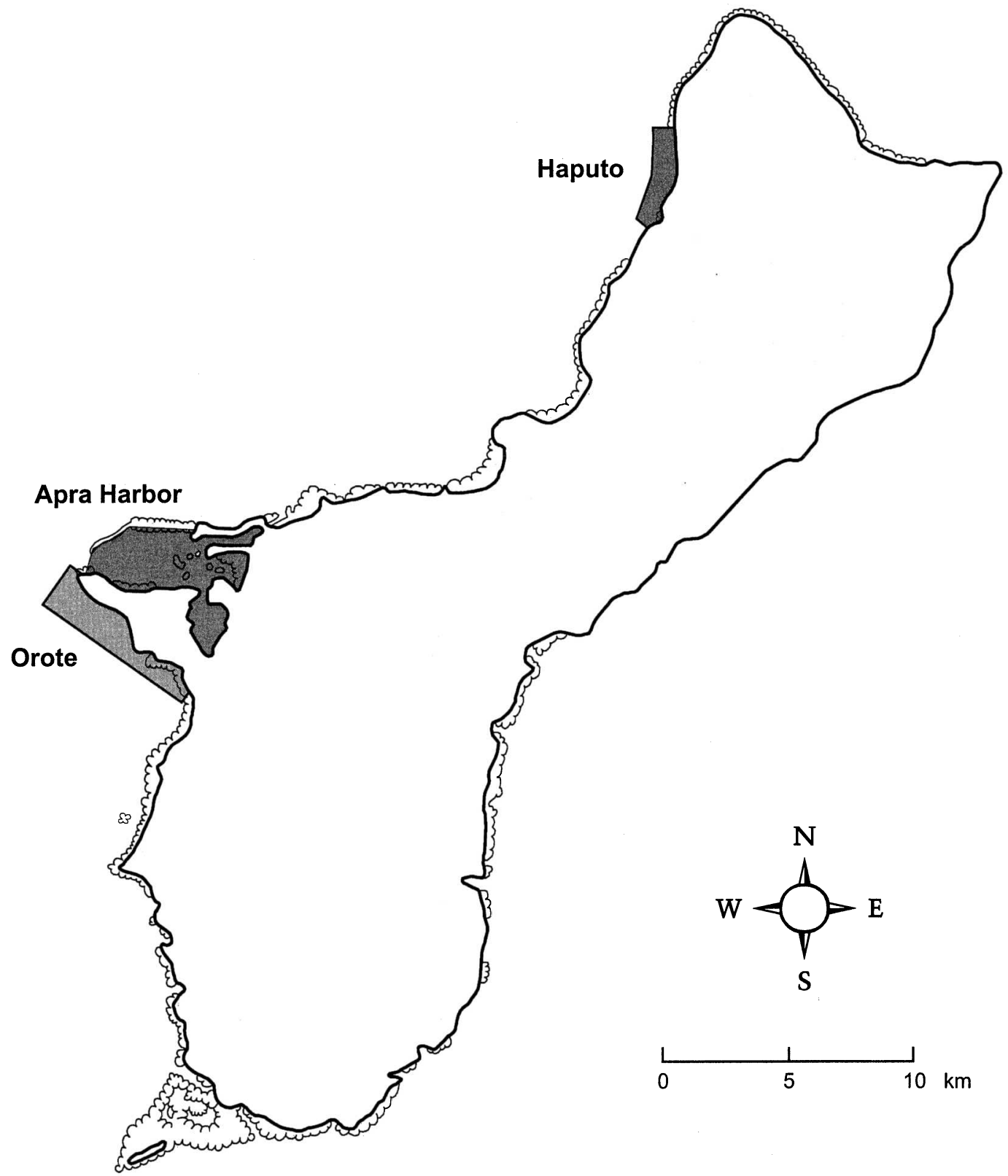

Figure 1. Map of Guam showing location of major biodiversity surveys.

harbor, which changed the southeastern arm of the lagoon from a reef-choked, silty embayment to a harbor with a uniform-depth, mud bottom, and (2) the fill projects that created the Dry Dock Island Peninsula, Po- laris Point, and artificial shorelines along the northeastern and southeastern boundaries of the harbor. These developments largely restricted the extent of natural shallow, silty fringing flats; inner, silty patch reefs; and 


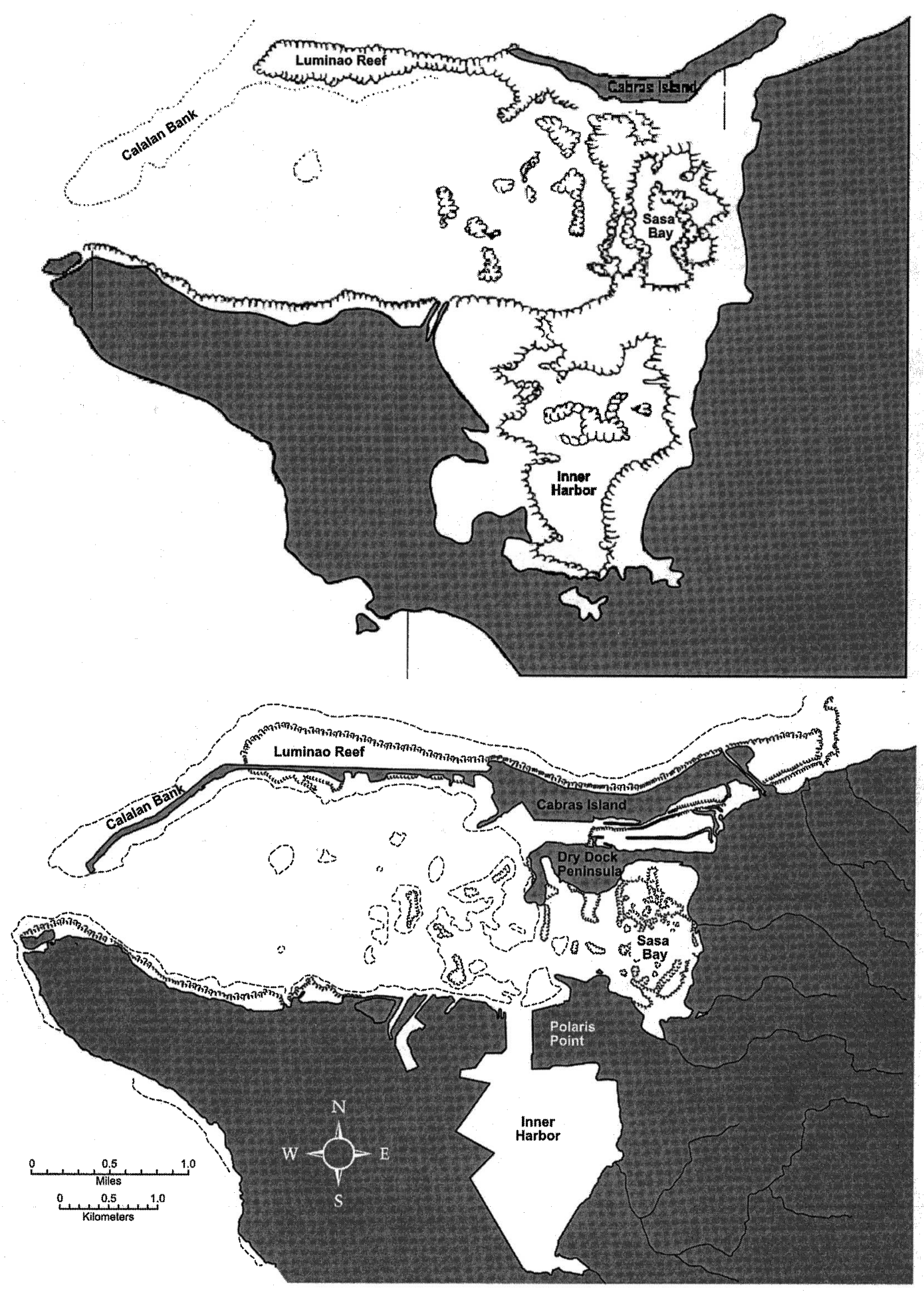

Figure 2. (Top) Apra Harbor in 1941. Note differences from current configuration depicted in the bottom view. 
mangroves within the harbor to the inner margin of Sasa Bay.

Despite these major alterations, Apra Harbor has a vibrant and thriving marine biota, including well-developed reefs, with some of the highest coral cover on Guam, and a diverse biota. Apra Harbor is thus unlike many larger ports, which have become substantially degraded for marine life (e.g., Morton 1990, Asakura 1992).

Physical, chemical, and biotic conditions all show pronounced east-to-west gradients in the harbor, related to the unidirectional exchange of water through the western entrance. For example, turbidity, the abundance of plankton, and benthic suspension feeders increase, and bottom sediments become finer eastward. Benthic habitats range from nearly oceanic reefs along the northwestern end of the Orote Peninsula, to silt-choked, lagoonal patch reefs; mud and silty sand bottoms; and mangroves in Sasa Bay and the Inner Harbor.

\section{Sources of Nonindigenous Species}

The main potential sources of nonindigenous species to Guam are purposeful introductions for fisheries and mariculture together with species that inadvertently arrived with such seed stock and hull and ballast transport with shipping traffic. The nature and extent of purposeful introductions of marine species is relatively well documented because they have been carried out largely by government agencies (Eldredge 1994), although accidental introduction of species hitchhiking on purposeful introductions (such as the parasitic gastropod Tathrella iredalei on tridacnines introduced to Guam) remains poorly explored.

There is much greater potential for hull than for ballast transport to Guam. With an importing economy, much more cargo is offloaded on the island than is taken away, minimizing the need for ballast discharge. Hull transport has considerably greater potential, including past opportunities on slow-moving, wood-hulled sailing ships and current opportunities on a variety of vessels ranging from recreational boats to container ships and military vessels, and even floating dry docks. The potential impact of the latter was demon- strated in the 1990s with the arrival of the dry dock Adept, from Subic Naval Station in the Philippines in 1992, and the Machinist, from Pearl Harbor, Hawaici, in 1999 (see discussion later in this article). Commercial shipping traffic to Guam originates mostly from the U.S. mainland via Hawai'i and to a lesser extent from Asia. The two largest freight companies, Matson Shipping and CSX Lines, route through Hawai'i to Guam and return to the United States via Asia. Smaller shipping lines, however, also connect Guam with several Asian cities, as well as with islands throughout Micronesia.

\section{Biotic Surveys}

We have carried out five major marine biodiversity surveys on Guam, two focusing on nonindigenous species (Figure 1). A preliminary nonindigenous species survey focusing on bivalves was funded by the Insular Pacific Marine Research Program and carried out in 1995-1996. A survey of introduced species on Guam, focusing on hard-bottom fauna, was funded by SeaGrant and carried out in 1998-2000. Three regional biodiversity and monitoring surveys were funded by the Department of Defense and focused on the marine faunas of Apra Harbor, southern Orote-Agat Bay, and the Pugua Patch ReefHaputo areas, respectively, between 1996 and 2001. Each of these surveys focused on hardbottom macrofauna, and specimens were individually collected in the field (i.e., we did not take bulk samples for subsequent laboratory analyses). We defined macrofauna as taxa whose species are largely $>1 \mathrm{~cm}$ in size. In each survey we first distinguished the major habitats in the survey area and then selected replicate stations within each habitat type. Each station was sampled by a team of divers and all macrofauna encountered was identified or collected if not immediately identifiable. Coverage of exposed taxa was generally good; cryptic species were less well sampled. A total of 682, 1252, and 944 species, respectively, was recorded in the last three surveys mentioned.

In addition to these structured surveys, there has been considerable attention in re- 


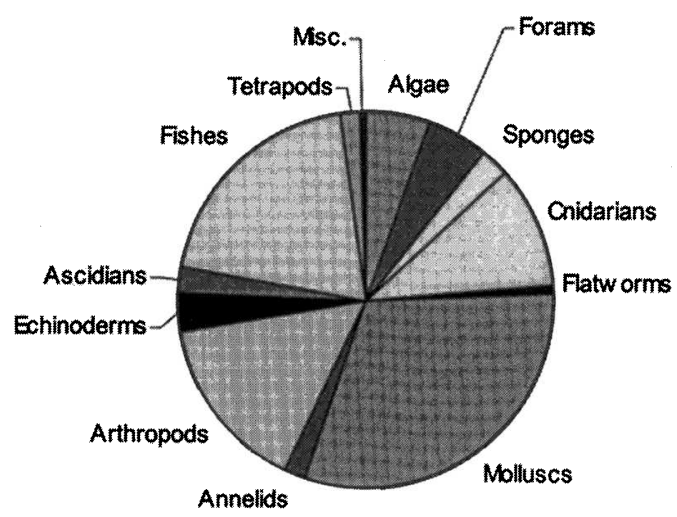

Figure 3. Documented marine biodiversity of Guam $(n=5507+$ species) (Paulay 2002).

cent years to Guam's biodiversity. Those efforts have culminated in a volume of Micronesica covering the marine biodiversity of Guam in a series of checklists (Paulay 2002). Although coverage is uneven both taxonomically and in terms of habitats surveyed, the checklists document $>5500$ marine species on the island (Figure 3). Macroalgae, scleractinians, echinoderms, and fishes are best known, and sponges, anthozoans, hydrozoans, macromollusks, stomatopods, decapod crustaceans, barnacles, and ascidians are moderately well known. In contrast, most worm groups, smaller crustaceans, bryozoans, most microinvertebrates, and microorganisms have been little studied. The hard-bottom biota is much better known than the soft-bottom biota. Nevertheless the checklists on hand are relatively accurate because they are based largely on each author's firsthand knowledge of their respective groups; thus multiple listings that often arise from literature-based compilations are minimized.

Each of the structured surveys, as well as general biodiversity prospecting before and concurrent to these, has emphasized recognizing morphospecies in the field. This approach allowed for the characterization of the habitat specificity and distribution of each species by fieldwork even before their taxonomic identification was completed. The knowledge gained about habitat specificity and local distributions has provided evidence for evaluating the likelihood that a particular species is nonindigenous. Identification of morphospecies was done either by specialists on the group (see Acknowledgments) or by us for well-known groups where available taxonomic literature permitted facile identification.

\section{Nonindigenous Species Recognition and Cautions}

Recognition of nonindigenous status is hampered by several factors on Guam. Few parts of the biota have been systematically studied to date, and taxa that have received such attention (e.g., algae, corals, and fishes) have been well documented for at most a few decades. Although there is a substantial Pleistocene record, this has received little attention, limited largely to well-skeletonized taxa such as corals and mollusks. Because there is little endemism in the fauna and it is impossible to rule out the adventive nature of most species, much of the biota would have to be classified as cryptogenic if one applied strict criteria to demonstrating indigenous status (Carlton 1996). Finally, the island lies in the relatively understudied and megadiverse Indo-West Pacific region, where substantial proportions of even common species are undescribed and the distributions of the majority of species remain poorly documented. The lack of taxonomic and distributional information hampers the application of geographic criteria for the identification of nonindigenous species. However, the biodiversity surveys that are now completed will provide background information against which potential future introductions can be assessed.

The main criteria we used for recognizing nonindigenous species on Guam were distribution outside Guam, and association with, or restriction to, artificial substrata, including vessels that could affect dispersal (Chapman and Carlton 1991). Restriction to harbor habitats was also taken into consideration, although as already mentioned, the unique environment of the harbor is also the sole habitat of numerous clearly indigenous species. A few species were known to have been introduced, and others are clearly or likely associated with introduced species. 
Although a widely disjunct distribution is highly suggestive of nonindigenous species status, it is difficult to apply this criterion to species whose distribution is relatively poorly documented. This is a concern especially in megadiverse settings such as the Indo-West Pacific, where much of the biodiversity remains undescribed and species ranges are often poorly documented. A circumtropical or cosmopolitan distribution itself is suggestive of nonindigenous species status; however three problems need to be taken into consideration with such taxa: (1) Are they really widespread? If yes, (2) are they capable of such wide dispersal without human agency? If not, (3) what is their home range? A few examples readily illustrate these problems.

It is becoming increasingly clear that many species that were previously thought to be widespread, and have at times been identified as nonindigenous species, are actually sibling species complexes (e.g., Poore 1996, Sponer et al. 1999). Morphological criteria alone may be insufficient or difficult to find for identifying some species in general and nonindigenous species in particular.

If a species is indeed circumtropical (or otherwise widespread), it may have reached its current distribution naturally. A widespread distribution can be relictual, if the organism can no longer disperse throughout its range or be actively maintained. For example, numerous species (e.g., the slipper lobster Parribacus antarcticus, the sea cucumber Holothuria impatiens, the gastropod Cymatium pileare) are recorded from both the tropical West Atlantic and the Indo-West Pacific, without other indication of being nonindigenous species. Many of these species likely became widespread before the closure of the Isthmus of Panama, but have not undergone sufficient morphological differentiation to be recognized as distinct species. This hypothesis can be tested readily with genetics (e.g., Colborn et al. 2001). Alternatively such IndoWest Pacific and West Atlantic populations may be in genetic contact (e.g., Graves 1998). Such actively maintained circumtropical distributions require not only an ability to disperse widely, but also a tolerance of cool water, because connections between the At- lantic and Indo-Pacific basins are possible only at temperate latitudes.

Species that are widespread as a result of human agency nevertheless clearly have an indigenous distribution and should not be assumed to be nonindigenous species throughout their range. For example, the circumtropical barnacle Balanus amphitrite is often considered to be a nonindigenous species, partly because of its widespread range, and partly because it is frequently associated with artificial substrata such as ship hulls. This species was thought to be nonindigenous at most locations and was so assumed by us on Guam initially. However, shells of what appear to be this species are present in late Pleistocene deposits in Apra Harbor, indicating that, at least in the Pleistocene, Guam was part of the indigenous range of this species. Balanus amphitrite itself is part of a major species complex (Henry and McLaughlin 1975), adding to the problem; fossil shells from Guam are currently under study by Patsy McLaughlin. In the past we also considered the possibility that the bivalves Chama brassica, Chama lazarus, and Lopha cristagalli were introduced to Guam. Guam lies at the edge of the distributional range of these species, and they are either much more common in or restricted to the harbor and are known to have been transported on hulls to the Hawaiian Islands (Paulay 1996). However, shells of all three are present in Pleistocene deposits, implying that a natural occurrence on Guam is more parsimonious.

Nevertheless, widespread ranges can also clearly result from anthropogenic transport. This is especially likely in taxa with poor dispersal abilities. Ascidians provide a compelling example: ascidian larvae are short lived (typically minutes to hours [Berrill 1950]), their fouling habits make them prone to human transport (Lambert 2002b, although also to natural rafting [e.g., Jokiel 1990]), and many species are circumtropical or cosmopolitan (e.g., 29\% of the identified fauna on Guam, $n=82$ ). Hydroids provide another likely example, where many morphospecies have short planktonic periods (e.g., in species lacking free-living medusae) yet very wide ranges (Kirkendale and Calder 2002). The 


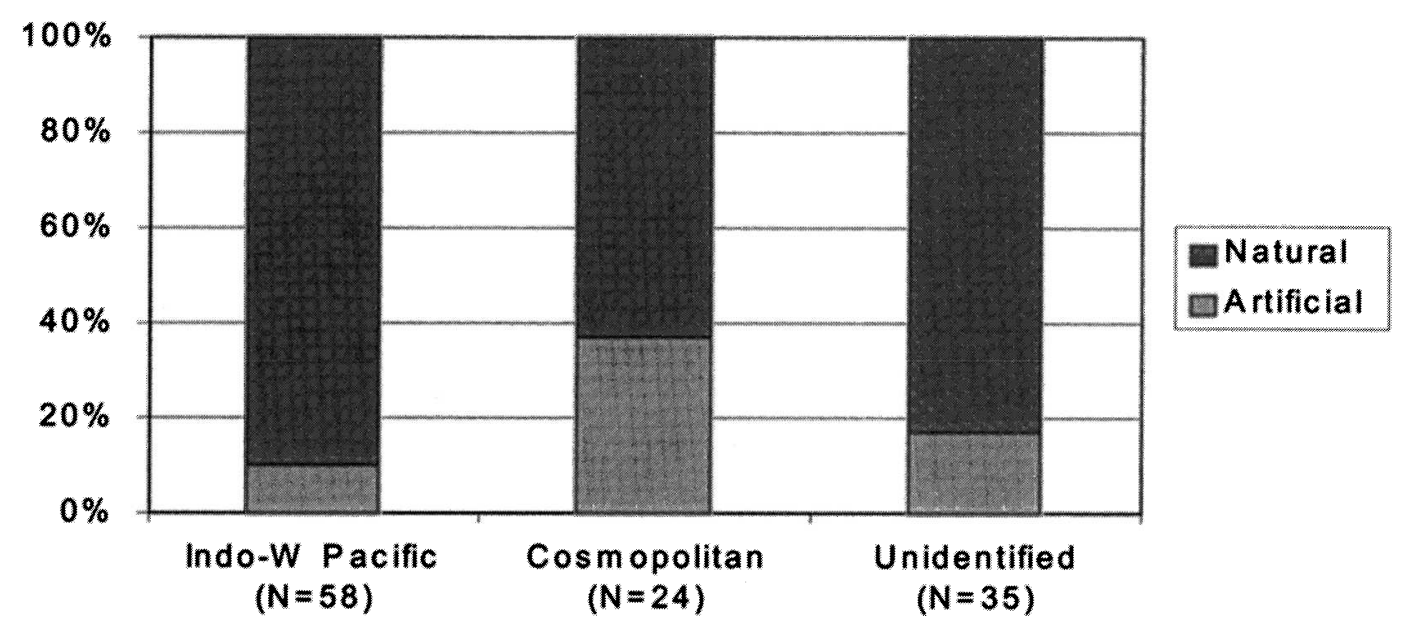

Figure 4. Ascidians of Guam. Indo-W Pacific, distribution limited to within Indo-West Pacific region; Cosmopolitan, distribution extends beyond Indo-West Pacific region; Unidentified, morphospecies remains unidentified, thus distribution unknown outside Guam; Artificial, encountered only on anthropogenic substrata; Natural, encountered on natural substrata only or also. $n$ (total) $=117$ species.

wide range of such taxa must be the result of dispersal during their sessile, adult stages, either through natural rafting or artificial fouling transport (cf. Jackson 1986).

One can test the hypothesis that widespread ranges are frequently the result of anthropogenic transport by examining whether geographic range is correlated with an independent criterion that is also thought to be indicative of introduced status. To do this we compared geographic range with restriction to artificial substrata in hydroids and ascidians, sessile taxa whose restriction to artificial versus natural substrata is easy to interpret and that have received taxonomic attention in recent surveys on Guam. Cosmopolitan ascidians are more likely to be restricted to artificial substrata than ascidians whose range is limited to the Indo-West Pacific (Figure 4 [two-way contingency test, $G=8.06, P<0.005])$. A statistically nonsignificant trend exists in hydroids, where $10 \%$ of Indo-West Pacific and 22\% of cosmopolitan species are only known from artificial substrata. Such correlation implies that cosmopolitan distribution is at least frequently the result of human transport. Nevertheless some cosmopolitan hydroids and ascidians show no other signs of being nonindigenous: they are unknown on artificial substrata, are not known within Apra Harbor, and are part of typical reef communities. Whether these represent nonindigenous species, indigenous species that have been carried outside the Indo-West Pacific, or species that have naturally become widespread remains to be tested.

Although cosmopolitan distributions are very common among the hydroids (53\%, $n=43)$ and ascidians $(29 \%, n=82)$ studied, they are much less common among other taxa. These disparities likely reflect differences in dispersal abilities among taxa, with the unusually high cosmopolitanism of hydroids and ascidians likely indicative of human-assisted dispersal of these groups.

For example, only $10 \%(n=192)$ of the echinoderms known from Guam have a range that extends outside the Indo-West Pacific, and most, if not all, of the wide-ranging species appear to have occupied their range naturally (Table 1). Thus 13 of the 19 widespread species extend only to the East Pacific, a contiguous region. Although the Indo-West Pacific and East Pacific are separated by the wide and formidable East Pacific open ocean barrier, this barrier is clearly breached by the propagules of numerous species (Rosenblatt and Waples 1986, Scheltema 1988, Lessios et al. 1996, 1998). That such pan-Pacific distributions are largely natural is underscored 
TABLE 1

Echinoderms from Guam with Extra-Indo-West Pacific Ranges

\begin{tabular}{|c|c|c|c|}
\hline Species & Range to ${ }^{a}$ & Notes & Reference \\
\hline Asteropsis carinifera & EP & & \\
\hline Acantbaster planci & EP & & \\
\hline Diadema savignyi & EP & Natural migrant & Lessios et al. 1996 \\
\hline Echinotbrix calamaris & $\mathrm{EP}$ & Natural migrant & Lessios et al. 1996 \\
\hline Echinotbrix diadema & EP & Natural migrant & Lessios et al. 1996, 1998 \\
\hline Echinometra oblonga & $\mathrm{EP}$ & Indigenous & Lessios et al. 1996 \\
\hline Stichopus borrens & $\mathrm{EP}$ & & \\
\hline Holotburia (Platyperona) difficilis & EP & & . \\
\hline Holotburia (Mertensiothuria) fuscocinerea & $\mathrm{EP}$ & & \\
\hline Holotburia (Tbymiosycia) billa & EP & & \\
\hline Holothuria (Lessonotburia) pardalis & $\mathrm{EP}$ & & \\
\hline Holotburia (Cystipus) rigida & $\mathrm{EP}$ & & \\
\hline Polyplectana kefersteini & EP & & \\
\hline Holotburia (Tbymiosycia) arenicola & $\mathrm{EP}, \mathrm{WA}$ & & \\
\hline Holotburia (Thymiosycia) impatiens & $\mathrm{EP}, \mathrm{WA}, \mathrm{EA}$ & & \\
\hline Amphipholis squamata & $\mathrm{EP}, \mathrm{WA}, \mathrm{EA}$ & Species complex & Sponer et al. 1999 \\
\hline Ophiactis savignyi & $\mathrm{EP}, \mathrm{WA}, \mathrm{EA}$ & Species complex & M. S. Roy, pers. comm. \\
\hline Linckia guildingi & WA & Genetically divergent & Williams 2000 \\
\hline Echinoneus cyclostomus & WA & & \\
\hline
\end{tabular}

${ }^{a}$ EP, East Pacific region; WA, West Atlantic region; EA, East Atlantic region (see Briggs 1974 for definitions).

by the preferential occurrence of pan-Pacific species on offshore islands compared with the continental mainland (Emerson 1991, Lessios et al. 1996, 1998). This bias makes sense for natural migrants, because these islands are closer to the source region and also have more appropriate reef habitats, but not for anthropogenic introductions, because the islands have sparse or no human populations. Clipperton Atoll, which has the largest proportion of Indo-West Pacific species in its biota, is the most isolated island in the region and is uninhabited. The remaining six species of extra-Indo-West Pacific echinoderms range into the Atlantic, and at least some of these are genetically divergent there, as expected for species whose distribution was set up before the closure of the Isthmus of Panama (Table 1).

\section{Recognition of Nonindigenous Species on Guam}

The term cryptogenic was introduced into the nonindigenous species literature to denote species that cannot be proven to be introduced or indigenous (Carlton 1996). As we already noted, it is difficult to be certain that any given species is indigenous to Guam because historical information from older surveys as well as from the local fossil record is quite limited, and the biota has few endemics. Thus we prefer an operational rather than a strict use of the terms introduced and cryptogenic. We used 11 indicators to assess the probability that a species was introduced to Guam and grouped these into three categories with regard to their likely accuracy ( $\mathrm{Ta}-$ ble 2). These indicators were used only in the absence of contrary evidence, such as from the fossil record (already mentioned). Primary indicators provide the strongest evidence for nonindigenous status, and species possessing any of them were considered introduced. Secondary indicators provide less powerful evidence of nonindigenous status, and species possessing them were considered cryptogenic, or if they possessed two of these traits, introduced. Tertiary indicators are the least powerful; species possessing two of these traits were considered cryptogenic. These criteria are probably more conservative in recognizing nonindigenous species than other methods, but also more objective. 
TABLE 2

Indicators of Nonindigenous Status Used

\begin{tabular}{ll}
\hline \hline Indicators & Compare w/C\&Ca \\
\hline Primary indicators & \\
A-Documented purposeful introduction & Criterion 1 \\
B-Appeared first with and on dry docks towed to Guam & Criteria 1 and 3 \\
C-Clear association with purposefully introduced nonindigenous species & Criterion 4 \\
Secondary indicators & \\
D-Restriction to artificial substrata & Criterion 5 \\
E-Extra-Indo-West Pacific, disjunct distribution & Criterion 7 \\
F-Within-Indo-West Pacific disjunct distribution & Criterion 7 \\
Tertiary indicators & Criterion 4 \\
G-Likely association with purposefully introduced nonindigenous species & Related to criteria 7 and 10 \\
H-Extra-Indo-West Pacific distribution & Related to criteria 3 and 7 \\
I-At range boundary and restricted to Apra Harbor & Criterion 5 \\
J-Frequent but not exclusive association with artificial substrata & \\
K-Opinion of specialist & \\
\hline
\end{tabular}

${ }^{a}$ Comparison with Chapman and Carlton's (1991) criteria.

\section{Nonindigenous Species on Guam}

Applying these criteria, we currently recognize 85 nonindigenous species on Guam (see Appendix). This list is clearly incomplete because many taxa have not been systematically collected and taxonomic work on others remains incomplete. Nevertheless it provides a basis for analysis. Forty-one species can be categorized as introduced and 44 as cryptogenic. As noted earlier the latter category in particular is applied stringently here; more liberal criteria would yield a larger number of cryptogenic taxa. Twelve (14\%) of the introduced species represent purposeful introductions, the rest accidental.

A striking feature of the nonindigenous biota of Guam is the preponderance of sessile species: $76 \%$ among all and $86 \%$ among accidentally introduced or cryptogenic species live attached. The same does not apply to intentionally introduced species, of which only $17 \%(n=12)$ are sessile. Only $3(15 \%$, $n=20$ ) of the mobile species have not been purposefully introduced or transported on ship hulls and thus are candidates for introduction via ballast water. Ten of the remainder were intentionally introduced to Guam, four arrived on dry dock hulls, one additional species has also been collected on dry dock hulls, and one was definitely and one likely associated with a purposeful introduction.

Sessile nonindigenous species include numerous sponges, hydroids, anemones, cemented and strongly byssate bivalves, barnacles, bryozoans, and ascidians. In contrast to their predominance among nonindigenous species, sessile species compose $<20 \%$ of Guam's documented marine fauna (cf. Figure 3). Because restriction to artificial substrata was one of the main indicators used to recognize nonindigenous species and because sessile species are more likely to be so recognized, the potential of partial circularity needs to be addressed. Another criterion for nonindigenous species status, extra-IndoWest Pacific distribution, can be used to test whether sessile species are indeed better represented among potentially introduced species than mobile species.

Both a comparison of sessile and mobile crustaceans and of sessile and mobile deuterostomes strongly suggests that the high incidence of sessile species among nonindigenous species is real. Thus the barnacle fauna of Guam includes a significantly higher proportion of species with extraregional distribution than the decapod crustacean fauna of the island $(13 \%$ versus $1.4 \%, n=30$ versus 552 ; $G=9.7 ; P<0.005)$. Similarly, ascidians on Guam have a much higher proportion of ex- 
tra-Indo-West Pacific species than do echinoderms $(28 \%$ versus $10 \%, n=82$ versus $192 ; G=13.7 ; P<0.001)$.

The preponderance of sessile species in the nonindigenous fauna supports the importance of hull transport compared with ballast transport as the main source of introduced species on Guam. Sessile species are abundant on ship hulls, especially on vessels, such as dry docks, that sit in place for a long period before being moved to a different location. Many of the nonindigenous species recognized on Guam, as well as other species that are thought to be indigenous to the island, were encountered fouling dry docks towed to Guam from the Philippines and Hawai'i (see following discussion). Furthermore, some of the groups best represented among the nonindigenous species do not have a long-lived larval stage; thus their persistence as larvae in ballast water is unlikely. Ascidians, represented by 31 species in the nonindigenous fauna, and with larval life spans of minutes to hours (Berrill 1950), are the most striking example. These results also fit with the observation made above that ballast water is rarely released in the vicinity of Guam, because of the importing economy of the island. In contrast, there are ample opportunities for hull transport.

Among hull transport opportunities, floating dry docks appear to be especially effective agents. Dry docks are large vessels that are used for ship repair and stay anchored in harbor environments for many years. Two dry docks were towed to Guam in the 1990s: the Adept in 1992 from Subic Bay Naval Base in the Philippines, and the Machinist in 1999 from Pearl Harbor, Hawai'i. The Machinist was also at Subic earlier, but had been stationed in Hawai' $i$ for a number of years. The Adept was briefly surveyed in 1992, and the Machinist more extensively in 1999. The Adept was covered with a relatively thin growth of sessile organisms, presumably because it was partially cleaned, but the $M a$ chinist arrived with a thick coat of sessile benthos. Both dry docks carried a diverse fauna, despite these differences. Sponges; hydroids; anemones; serpulid, spirorbid, and sabellid polychaetes; oysters; pteriid bivalves; barnacles; crabs; bryozoans; ascidians; and fishes were seen associated with the $A d e p t$, and an even more diverse biota documented for the Machinist. A detailed analysis of the latter is planned once identification work is completed.

The Machinist took 6 weeks to transit from Hawai'i to Guam, at an average speed of $\sim 5.5$ $\mathrm{km} / \mathrm{hr}$ (3 knots). Ralph DeFelice (1999) surveyed the dry dock shortly before it left $\mathrm{Ha}$ wai' $i$ and recorded 113 species. We surveyed it a few days after it arrived on Guam and collected numerous species, 42 of which have been identified to date. Eighty-two percent of these were encountered by DeFelice (1999) in Hawai' $i$, and over half of the identified taxa represent new records for Guam.

Although transport by the Machinist was very effective, because a large proportion of the associated species arrived alive on Guam, many species did not survive long after arrival. Most of the sessile bivalve species associated with the dry dock were highly emaciated, with watery, small bodies within their shells, and appeared to have exhausted much of their energy reserves. This presumably reflects starvation during the long journey across the highly oligotrophic waters of the North Pacific gyre, especially in comparison with the rich waters of their harbor of origin. Most of the mollusks transported by the Machinist to Guam were dead within a year of their arrival in Apra Harbor (Table 3).

\section{TABLE 3}

Fate of Mollusks Introduced on the Machinist

\begin{tabular}{lcc}
\hline \hline Species & $\begin{array}{c}\text { July } 1999 \\
\text { (<eek after arrival) }\end{array}$ & $\begin{array}{c}\text { August } \\
2000\end{array}$ \\
\hline Chama maceropbylla & Abundant & 1 seen alive \\
Chama fibula & Abundant & 0 seen alive \\
Chama brassica $^{a}$ & Occasional & 0 seen alive \\
Chama pacifica $^{a}$ & Common & 0 seen alive \\
Crepidula aculeata $_{\text {Cucibulum spinosum }}$ & Common & 0 seen alive \\
Anomia nobilis & Common & 0 seen alive \\
Saccostrea cucullata & Common & O seen alive \\
\hline
\end{tabular}

Note: Both surveys based on swim through under hull of dry dock, with $>1 \mathrm{hr}$ search time for mollusks. Although dead shells of all the cemented bivalves remained common in August, only two species were encountered alive.

${ }^{a}$ Indigenous on Guam. 
Although the cause of these mortalities is unclear, starvation during transport likely contributed toward it. In contrast with the high mortality of mollusks after arrival, the transported sponge fauna appears to have remained largely intact, although identification work on this fauna remains to be completed. However, on the basis of their field appearance, many if not most species of sponges encountered in July 1999 were still on the Machinist's hull in August 2000.

\section{Impact of Nonindigenous Species on Guam}

Entry of marine nonindigenous species is usually port-associated, and ports are not randomly distributed among marine habitats, but preferentially located in protected environments such as large estuaries, lagoons, and bays. As a result, anthropogenic biotic interchange is much more likely among such protected habitats than among habitats along open coasts. Consequently the biota of protected habitats is much more vulnerable to disturbance or extirpation by nonindigenous species than the biota of other habitats. Two aspects of the impact of nonindigenous species are the extent to which (1) nonindigenous species have spread out of the recipient habitat into surrounding habitats, and (2) the habitats of the recipient environment are occupied, and indigenous species impacted, by nonindigenous species. Both impacts appear to be relatively limited on Guam to date.

Only $23 \%$ of the nonindigenous species recognized on Guam have been found in natural habitats outside Apra Harbor: six introduced and 14 cryptogenic species. These include three purposeful introductions: two brackish-water fish species and the gastropod Trochus niloticus. The latter species is now abundant around Guam and the basis of a local fishery. Ten $(50 \%)$ of the nonindigenous species that have been encountered outside Apra Harbor are ascidians; none of these is abundant. Aside from Trochus niloticus, only the cryptogenic hydroids Pennaria disticha and Thyroscyphus fruticosus are relatively common outside Apra Harbor. More striking is the lack of spread of some nonindigenous species that are well established in
Apra Harbor, such as the Caribbean barnacle Chthamalus proteus and the sponge Iantbella basta.

Even within Apra Harbor, nonindigenous species are not abundant on natural substrata. Over half (46) of the recognized nonindigenous species are restricted to artificial substrata (e.g., moorings), and even those that are not so restricted are often most abundant on artificial bottoms. Although nonindigenous species are important as bottom cover on anthropogenic substrata, they are currently inconsequential on natural bottoms. A survey of the sessile biota on a patch reef and adjacent mooring buoys in Apra Harbor revealed that although nonindigenous species were absent on the former, they have become important space occupiers on the latter (Figure 5). These results support the hypothesis that diverse coral reefs are relatively difficult to invade.

The preferential invasion of artificial substrata by nonindigenous species is partly a reflection of differences in habitat preference among invading and indigenous taxa. That artificial substrata attract a different community has been clearly demonstrated (Connell and Glasby 1999, Glasby 1999, Connell 2000), and because the majority of nonindigenous species appear to disperse by hull transport to Guam, their preference for artificial bottoms is not unexpected.

\section{Conclusions}

Coral reefs are among the most vulnerable marine ecosystems, currently facing a variety of anthropogenic onslaughts ranging from overfishing to global warming (e.g., Wilkinson 2000, Jackson et al. 2001). However, as diverse ecosystems, reefs would be expected to be relatively resistant to invasion (Vermeij 1991). The survey for nonindigenous species on Guam has revealed two sides to this expectation. As have other major ports (Ruiz et al. 1997), Guam has been invaded by numerous nonindigenous species. However the spread and impact of nonindigenous species have as yet been relatively limited. Unlike environments such as San Francisco Bay, where nonindigenous species dominate many 


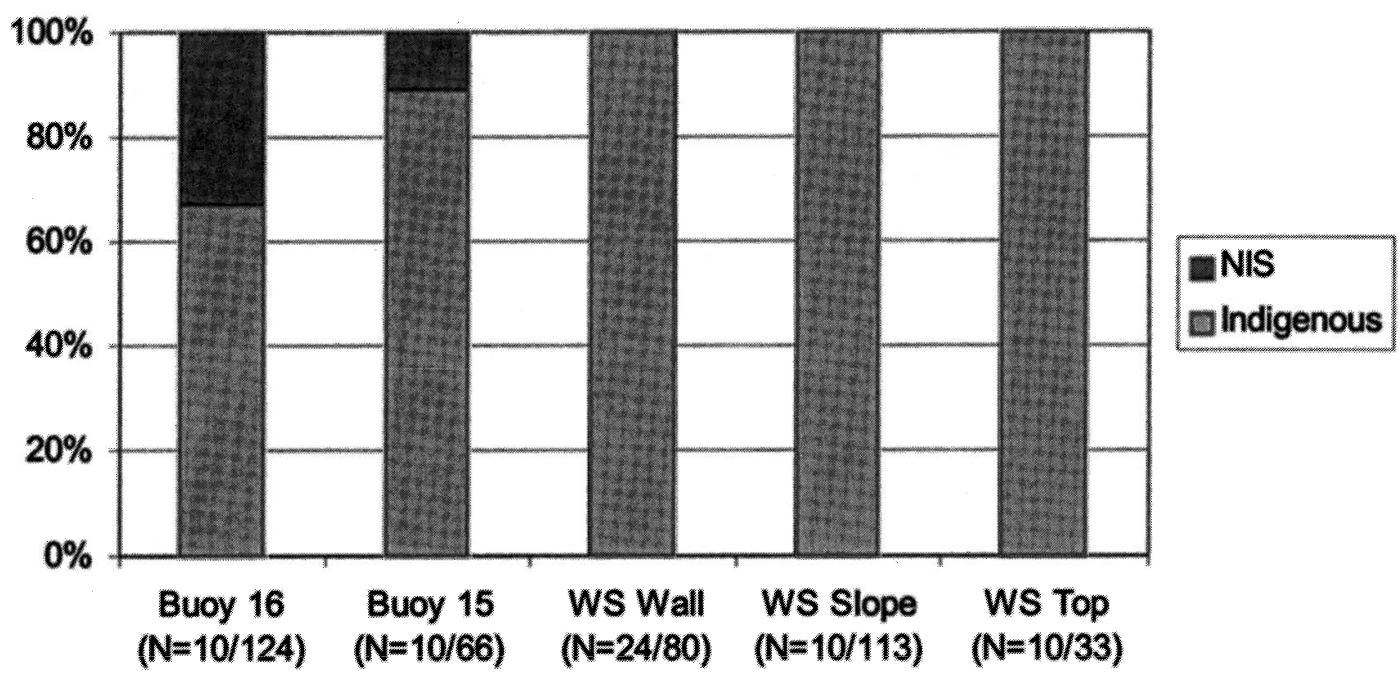

FIgURE 5. Impact (\% cover) of nonindigenous species (NIS) on artificial and natural substrata. Western Shoals (WS) is a large patch reef in Apra Harbor, with three microhabitats (wall, slope, top) sampled. Buoys 15 and 16 are mooring buoys within $200 \mathrm{~m}$ of Western Shoals. $n$, number of quadrat samples/number of point hits in all quadrats. Lineintercept quadrats used with 16 intercepts/quadrat; only faunal hits were counted, rest of the cover comprised algae or detritus.

habitats (Cohen and Carlton 1998), nonindigenous species on Guam are relatively rare on natural reef bottoms, although abundant on artificial substrata. Even Pearl Harbor in $\mathrm{O}^{\prime}$ ahu has been invaded to a much greater extent than Apra Harbor both in terms of diversity and abundance of nonindigenous species (Coles et al. 1999).

The difference between invasion and impact on Guam and those in other locations is the result of several factors. First, although Guam is the metropolitan center of Micronesia and Apra Harbor is the major regional port, both the population of Guam and shipping traffic to Apra Harbor are much lower than in Pearl Harbor, San Francisco Bay, or other major continental ports. Second, the reefal environment of Apra Harbor is still relatively intact, with diverse reef communities. This contrasts with Pearl Harbor, which although lying in the coral reef belt, has few reef corals living within its confines (Coles et al. 1997). Thus, opportunities for invasion are more limited and the potential resistance of indigenous communities to invasion is higher because of both their innate diversity and only moderately disturbed nature. Al- though marine nonindigenous species problems are currently relatively minor on Guam, the potential is there for disaster: the islandwide spread of several nonindigenous species has shown that tropical reef communities are not immune to invasion.

Like most other small, oceanic islands, Guam does not have a large industrial base and as a result has a mostly importing economy. This is reflected in the characteristics of the nonindigenous biota. Opportunities for ballast transport have been relatively limited, and hull transport appears to have been the predominant avenue of invasion. The preponderance of a sessile lifestyle among the nonindigenous fauna clearly reflects this bias. The opportunities for hull transport have been strongly demonstrated by the entire biotas that two dry docks brought to the island in the 1990s.

\section{ACKNOWLEDGMENTS}

We thank Chris Bassler, Victor Bonito, Frank Cushing, Butch Irish, Trina Leberer, Raphael Ritson-Williams, and John Starmer for help with fieldwork. We thank the fol- 
lowing taxonomists for help with species identifications or discussion of introduced status: John Hooper, Michelle Kelly, Rob van Soest (sponges), Dale Calder (hydroids), Gerhard Jarms (coronates), Dick Randall (corals), Phil Alderslade (octocorals), Koos den Hartog (anemones), Barry Smith (prosobranchs), Clay Carlson (opisthobranchs), Peter Castro, Bella Galil, Colin McLay, Peter $\mathrm{Ng}$, Masatsune Takeda (crabs), Junji Okuno, Charles Fransen (shrimp), Tin-Yam Chan (shrimp and lobsters), Patsy McLaughlin (paguroids), Kiyo Asami, Yoshi Hisatsune, Bill Newman (barnacles), Charles Messing (crinoids), Claude and Françoise Monniot (ascidians), and Rob Myers (fishes).

\section{Literature Cited}

Asakura, A. 1992. Recent introductions of marine benthos into Tokyo Bay (review): Process of invasion into an urban ecosystem with discussion on the factors inducing their successful introduction. J. Nat. Hist. Mus. Inst. Chiba 2:1-14.

Bailey-Brock, J. H. 2002. Coral reef polychaetes of Guam and Saipan, Mariana Islands. Micronesica 35: (in press).

Berrill, N. J. 1950. The Tunicata. The Ray Society, London.

Briggs, J. C. 1974. Marine zoogeography. McGraw-Hill, New York.

Carlton, J. T. 1996. Biological invasions and cryptogenic species. Ecology 77:16531655.

Carlton, J. T., and J. Hodder. 1995. Biogeography and dispersal of coastal marine organisms: Experimental studies on a replica of a 16th-century sailing vessel. Mar. Biol. (Berl.) 121:721-730.

Chapman, J. W., and J. T. Carlton. 1991. A test of criteria for introduced species: The global invasion by the isopod Synidotea laevidorsalis (Miers, 1881). J. Crustacean Biol. 11:386-400.

Cohen, A. T., and J. T. Carlton. 1998. Accelerating invasion rate in a highly invaded estuary. Science (Washington, D.C.) 279:555-558.

Colborn, J., R. E. Crabtree, J. B. Shaklee,
E. Pfeiler, and B. W. Bowen. 2001. The evolutionary enigma of bonefishes (Albula spp.): Cryptic species and ancient separations in a globally distributed shorefish. Evolution 55:807-820.

Coles, S. L., R. C. DeFelice, L. G. Eldredge, and J. T. Carlton. 1997. Biodiversity of marine communities in Pearl Harbor, Oahu, Hawaii with observations on introduced exotic species. Bishop Mus. Tech. Rep. 10.

. 1999. Historical and recent introductions of non-indigenous marine species into Pearl Harbor, Oahu, Hawaiian Islands. Mar. Biol. (Berl.) 135:147-158.

Connell, S. D. 2000. Floating pontoons create novel habitats for subtidal epibiota. J. Exp. Mar. Biol. Ecol. 247:183-194.

Connell, S. D., and T. M. Glasby. 1999. Do urban structures influence local abundance and diversity of subtidal biota? A case study from Sydney Harbour, Australia. Mar. Environ. Res. 47:373-387.

DeFelice, R. C. 1999. Fouling marine invertebrates on the floating dry dock USS Machinist in Pearl Harbor prior to its move to Apra Harbor, Guam. Hawai'i Biological Survey, Bishop Museum, Honolulu.

Eldredge, L. G. 1994. Perspectives in aquatic exotic species management in the Pacific islands. Vol. 1. Introductions of commercially significant aquatic organisms to the Pacific islands. South Pac. Comm. Inshore Fish. Res. Proj. Tech. Doc. 7:1-127.

Eldredge, L. G., and G. Paulay. 1996. Baseline biodiversity assessment of natural harbors at Guam and Hawaii. Report to Insular Pacific Regional Marine Research Program. University of Hawai'i Library, Honolulu.

Emerson, W. K. 1991. First records for Cymatium mundum (Gould) in the eastern Pacific Ocean, with comments on the zoogeography of the tropical trans-Pacific tonnacean and non-tonnacean prosobranch gastropods with Indo-Pacific faunal affinities in West American waters. Nautilus 105:62-80.

Glasby, T. M. 1999. Differences between subtidal epibiota on pier pilings and rocky 
reefs at marinas in Sydney, Australia. Estuarine Coastal Shelf Sci. 48:281-290.

Graves, J. E. 1998. Molecular insights into the population structures of cosmopolitan marine fishes. J. Hered. 89:427-437.

Henry, D. P., and P. A. McLaughlin. 1975. The barnacles of the Balanus amphitrite complex (Cirripedia, Thoracica). Zool. Verh. (Leiden) 141:1-254.

Jackson, J. B. C. 1986. Modes of dispersal of clonal benthic invertebrates: Consequences for species' distributions and genetic structure of local populations. Bull. Mar. Sci. 39:588-606.

Jackson, J. B. C., M. X. Kirby, W. H. Berger, K. A. Bjorndal, L. W. Botsford, B. J. Bourque, R. H. Bradbury, R. Cooke, J. Erlandson, J. A. Estes, T. P. Hughes, S. Kidwell, C. B. Lange, H. S. Lenihan, J. M. Pandolfi, C. H. Peterson, R. S. Steneck, M. J. Tegner, and R. R. Warner. 2001. Historical overfishing and the recent collapse of coastal ecosystems. Science (Washington, D.C.) 293:629-638.

Jokiel, P. L. 1990. Long-distance dispersal by rafting: Reemergence of an old hypothesis. Endeavour (n. s.) 14:66-73.

Kelly, M., J. Hooper, V. Paul, G. Paulay, R. van Soest, and W. de Weerdt. 2002. Taxonomic inventory of sponges (Porifera) of the Mariana Islands. Micronesica 35: (in press).

Kirch, P. 2000. On the roads of the winds: An archaeological history of the Pacific Islands. University of California Press, Berkeley.

Kirkendale, L., and D. R. Calder. 2002. Hydroids (Cnidaria: Hydrozoa) in collections from Guam and the Commonwealth of the Northern Marianas Islands (CNMI). Micronesica 35: (in press).

Lambert, G. 2002a. Marine biodiversity of Guam: The Ascidiacea. Micronesica 35: (in press).

. 2002b. Nonindigenous ascidians in tropical waters. Pac. Sci. 56:291-298.

Lessios, H. A., B. D. Kessing, and G. M. Wellington. 1996. Indo-Pacific echinoids in the tropical eastern Pacific. Coral Reefs 15:133-142.

Lessios, H. A., B. D. Kessing, and D. R.
Robertson. 1998. Massive gene flow across the world's most potent marine biogeographic barrier. Proc. R. Soc. Lond. 265:583-588.

Maragos, J. E. 1995. Revised checklist of extant shallow-water coral species from Hawaii (Cnidaria: Anthozoa: Scleractinia). Bishop Mus. Occas. Pap. 42:54-55.

McConnell, J., and R. Muniappan. 1991. Introduced ornamental plants that have become weeds on Guam. Micronesica Suppl. $3: 47-50$.

Morton, B. 1990. Pollution and the subtropical inshore hydrographic environment of Hong Kong. Pages 3-30 in B. Morton. The marine flora and fauna of Hong Kong and southern China 2. Vol. 1. Introduction and taxonomy. Hong Kong University Press, Hong Kong.

Nafus, D., and I. Schreiner. 1989. Biological control activities in the Mariana Islands from 1911 to 1988. Micronesica 22:65106.

Paulay, G. 1996. New records and synonymies of Hawaiian bivalves. Bishop Mus. Occas. Pap. 45:18-29.

- 1997. Diversity and distribution of reef organisms. Pages 298-353 in C. E. Birkeland, ed. Life and death of coral reefs. Chapman and Hall, New York.

— ed. 2002. The marine biodiversity of Guam: Annotated checklists of the marine biota of a Pacific island. Micronesica 35: (in press).

Paulay, G., and C. Meyer. 2001. Biodiversity and endemism in the Indo-West Pacific reef fauna: How much and where? Proc. 9th Int. Coral Reef Symp. (abstract) (in press).

Poore, G. C. B. 1996. Species differentiation in Synidotea (Isopoda: Idoteidae) and recognition of introduced marine species: A reply to Chapman and Carlton. J. Crustacean Biol. 16:384-394.

Randall, R. H. 2002. An annotated checklist of hydrozoan and scleractinian corals collected from Guam and other Mariana Islands. Micronesica 35: (in press).

Rosenblatt, R. H., and R. S. Waples. 1986. A genetic comparison of allopatric populations of shore fish species from the eastern 
and central Pacific Ocean: Dispersal and vicariance. Copeia 1986:275-284.

Ruiz, G. M., J. T. Carlton, E. D. Grosholz, and A. H. Hines. 1997. Global invasions of marine and estuarine habitats by nonindigenous species: Mechanisms, extent, and consequences. Am. Zool. 37:621-632.

Savidge, J. A. 1987. Extinction of an island forest avifauna by an introduced snake. Ecology 68:660-668.

Scheltema, R. S. 1988. Initial evidence for the transport of teleplanic larvae of benthic invertebrates across the East Pacific barrier. Biol. Bull. (Woods Hole) 174:145-152.

Smith, B. D. 1987. Growth rate, distribution, and abundance of the introduced topshell Trocbus niloticus Linnaeus on Guam, Mariana Islands. Bull. Mar. Sci. 41:466-474.

Southward, A. J., R. S. Burton, S. L. Coles, P. R. Dando, R. DeFelice, J. Hoover, P. E. Parnell, T. Yamaguchi, and W. A. Newman. 1998. Invasion of Hawaiian shores by an Atlantic barnacle. Mar. Ecol. Prog. Ser. 165:119-126.
Sponer, R., M. S. Roy, and P. V. Mladenov. 1999. Molecular evolution of Amphipholis squamata (Echinodermata: Ophiuroidea): High genetic differences among populations. Pages 405-408 in C. Carnevali, M. Daniela, and F. Bonasoro, eds. Echinoderm research 1998. Proceedings of the Fifth European Conference on Echinoderms, Milan, Italy, 7-12 September 1998. A. A. Balkema, Rotterdam and Brookfield. Stachowicz, J. J., R. B. Whitlatch, and R. W. Osman. 1999. Species diversity and invasion resistance in a marine ecosystem. Science (Washington, D.C.) 286:15771579.

Vermeij, G. J. 1991. When biotas meet: Understanding biotic interchange. Science (Washington, D.C.) 253:1099-1104.

Wilkinson, C., ed. 2000. Status of coral reefs of the world: 2000. Australian Institute of Marine Science, Townsville.

Williams, S. T. 2000. Species boundaries in the starfish genus Linckia. Mar. Biol. (Berl.) 136:137-148. 
Appendix

Nonindigenous Species Recorded on Guam

\begin{tabular}{|c|c|c|c|c|c|c|c|c|c|}
\hline Species & Status $^{a}$ & Sessile ${ }^{b, c}$ & Apra $^{c, d}$ & Out ${ }^{c, e}$ & Extra-IWP $c, f$ & Artif. only ${ }^{c, g}$ & Artif..,$b$ & Evidence $^{i}$ & Persistence ${ }^{j}$ \\
\hline \multicolumn{10}{|l|}{ Porifera } \\
\hline Callyspongia aff. fibrosa & $\mathrm{C}$ & 1 & 1 & 0 & $?$ & 1 & 1 & $\mathrm{D}, 4$ & Established \\
\hline Ianthella basta & $\mathrm{C}$ & 1 & 1 & 0 & 0 & 0 & 0 & $\mathrm{~F}, 4$ & Established \\
\hline Mycale (Crambia) sp. 1 & $\mathrm{C}$ & 1 & 1 & 0 & $?$ & 1 & 1 & $\mathrm{D}, 4$ & Established \\
\hline Niphates sp. 1 & $\mathrm{C}$ & 1 & 1 & 0 & $?$ & 1 & 1 & $\mathrm{D}, 4$ & Established \\
\hline Tedania cf. ignis & $\mathrm{I}$ & 1 & 1 & 0 & 1 & 1 & 1 & $\mathrm{D}, \mathrm{E}, 4$ & Established \\
\hline \multicolumn{10}{|l|}{ Anthozoa } \\
\hline Actiniaria sp. 1 & $\mathrm{C}$ & 1 & 1 & 0 & $?$ & 1 & 1 & $\mathrm{D}$ & Established \\
\hline Actiniaria sp. 2 & $\mathrm{C}$ & 1 & 1 & 0 & ? & 1 & 1 & $\mathrm{D}$ & Established \\
\hline Actiniaria sp. 3 & $\mathrm{C}$ & 1 & 1 & 0 & ? & 1 & 1 & $\mathrm{D}$ & Established \\
\hline \multicolumn{10}{|l|}{ Hydrozoa } \\
\hline Clytia bemisphaerica & $\mathrm{C}$ & 1 & 1 & 0 & 1 & 1 & 1 & $\mathrm{D}, \mathrm{H}, 5$ & $?$ \\
\hline Clytia latitheca & $\mathrm{C}$ & 1 & 1 & 1 & 1 & 0 & 1 & $\mathrm{E}, \mathrm{J}, 5$ & ? \\
\hline Clytia linearis & $\mathrm{C}$ & 1 & 1 & 1 & 1 & 0 & 1 & $\mathrm{H}, \mathrm{G}, \mathrm{J}, 5$ & Established \\
\hline Clytia noliformis & $\mathrm{I}$ & 1 & 1 & 0 & 1 & 1 & 1 & $\mathrm{D}, \mathrm{E}, 5$ & ? \\
\hline Corydendrium parasiticum & $\mathrm{C}$ & 1 & 1 & 1 & 1 & 0 & 1 & $\mathrm{H}, \mathrm{J}, 5$ & Established \\
\hline Ectopleura pacifica & $\mathrm{I}$ & 1 & 1 & 0 & 0 & 1 & 1 & $\mathrm{D}, \mathrm{F}, 5$ & Established \\
\hline Obelia dichotoma & $\mathrm{I}$ & 1 & 1 & 0 & 1 & 1 & 1 & $\mathrm{~B}, \mathrm{D}, \mathrm{H}, 5$ & ? \\
\hline Pennaria disticha & $\mathrm{C}$ & 1 & 1 & 1 & 1 & 0 & 1 & $\mathrm{H}, \mathrm{J}, 5$ & Established \\
\hline Thyroscyphus fruticosus & $\mathrm{C}$ & 1 & 1 & 1 & 0 & 0 & 1 & $\mathrm{~J}, \mathrm{~K}, 5$ & Established \\
\hline Turritopsis nutricula & $\mathrm{C}$ & 1 & 1 & 0 & 1 & 1 & 1 & $\mathrm{D}, \mathrm{H}, 5$ & Established \\
\hline \multicolumn{10}{|l|}{ Polychaeta } \\
\hline Salmacina dysteri & $\mathrm{C}$ & 1 & 1 & 0 & 1 & 1 & 1 & $\mathrm{D}, 1$ & Established \\
\hline Oenone fulgida & I & 1 & 1 & 0 & 0 & 1 & 1 & $\mathrm{~B}, 1$ & ? \\
\hline Timarete caribous & $\mathrm{I}$ & 1 & 1 & 0 & ? & 1 & 1 & $\mathrm{~B}, 1$ & ? \\
\hline Thelepus setosus & $\mathrm{I}$ & 1 & 1 & 0 & 1 & 1 & 1 & $\begin{array}{l}\mathrm{D}, \mathrm{1} \\
\mathrm{B}, 1\end{array}$ & $?$ \\
\hline Sabellastarte sp. & $\mathrm{I}$ & 1 & 1 & 0 & $?$ & 1 & 1 & $\mathrm{~B}, 1$ & $?$ \\
\hline \multicolumn{10}{|l|}{ Gastropoda } \\
\hline Cellana mazatlandica & I & 0 & 0 & 0 & 0 & 0 & 0 & A, 2 & Extirpated \\
\hline Crepidula aculeata & I & 0 & 1 & 0 & 1 & 1 & 1 & $\mathrm{~B}$ & Extirpated \\
\hline Crucibulum spinosum & I & 0 & 1 & 0 & 1 & 1 & 1 & $\mathrm{~B}$ & Extirpated? \\
\hline Tatbrella iredalei & I & 0 & 0 & 0 & 0 & 0 & 0 & $\mathrm{C}$ & Extirpated? \\
\hline Trocbus niloticus & I & 0 & 1 & 1 & 0 & 0 & 0 & A, 7 & Established \\
\hline \multicolumn{10}{|l|}{ Bivalvia } \\
\hline Anomia nobilis & I & 1 & 1 & 0 & 0 & 1 & 1 & B & ? \\
\hline Chama fibula & I & 1 & 1 & 0 & 0 & 1 & 1 & B & $?$ \\
\hline Chama macerophylla & I & 1 & 1 & 0 & 1 & 1 & 1 & $\begin{array}{l}\mathrm{D} \\
\mathrm{B}\end{array}$ & $?$ \\
\hline Crassostrea echinata & I & 1 & 1 & 0 & 0 & 0 & 0 & A, 2 & Extirpated? \\
\hline
\end{tabular}


Crassostrea gigas

Isognomon ephippium

Trapezium sublaevigatum

Tridacna derasa

Tridacna gigas

Cirripedia

Balanus eburneus

Chthamalus proteus

Malacostraca

Metopograpsus oceanicus

Charybdis belleri

Penaeus monodon

Penaeus stylirostris

Penaeus vannamei

Bryozoa

Amatbia distans

Bryozoan sp. 1 (metallic)

Schizoporella serialis

Echinodermata

Ophiactis savignyi

Ascidiacea

Ascidiacea sp. A

Ascidia sp. B

Ascidia sydneiensis

Botryllus cf. simodensis

Botryllus niger

Botryllus sp. A

Botryllus sp. B

Cnemidocarpa irene

Didemnum perlucidum

Didemnum psammatbodes

Diplosoma listerianum

Diplosoma sp. A

Herdmania insolita

Herdmania pallida

Lissoclinum fragile

Microcosmus exasperatus

Microcosmus belleri

Microcosmus pupa

Perophora multiclathrata

Perophora sagamiensis

Phallusia nigra

Polyandrocarpa sagamiensis

Polycarpa aurita

Established

$\mathrm{D}$

Established

Established

A, 2
A, 2

Established

In mariculture

A

In mariculture

D

Established

D Established

H, J Established

H, J

Established

D, 6

$\mathrm{D}, 6$

D, H, 6

$\mathrm{D}, 6$

H, J, 6

D, 6

$\mathrm{D}, 6$

H, J, 6

D, H, 6

H, J, 6

D, H, 6

D, 6

$\mathrm{D}, 6$

H, J, 6

$\mathrm{D}, \mathrm{H}, 6$

D, H, 6

H, J, 6

$\mathrm{D}, 6$

H, J, 6

J, K, 6

D, H, 6

D, 6

D, 6

Established

Established

Established

Established

Established

Established

Established

Established

Established

Established

Established

Established

Established

Established

Established

Established

Established

Established

Established

Established

Established

Established

Established 
Appendix (continued)

\begin{tabular}{|c|c|c|c|c|c|c|c|c|c|}
\hline Species & Status $^{a}$ & Sessile ${ }^{b, c}$ & Apra $^{c, d}$ & Out ${ }^{c, e}$ & Extra-IWP $c, f$ & Artif. only ${ }^{c, g}$ & Artif., & Evidence $^{i}$ & Persistence \\
\hline Polyclinum constellatum & $\mathrm{I}$ & 1 & 1 & 0 & 1 & 1 & 1 & $\mathrm{D}, \mathrm{H}, 6$ & Established \\
\hline Pyura cf. robusta & $\mathrm{C}$ & 1 & 1 & 1 & 0 & 0 & 1 & $\mathrm{~J}, \mathrm{~K}, 6$ & Established \\
\hline Pyura confragosa & $\mathrm{C}$ & 1 & 1 & 0 & 0 & 1 & 1 & $\mathrm{D}, 6$ & Established \\
\hline Pyura curvigona & $\mathrm{C}$ & 1 & 1 & 1 & 0 & 0 & 1 & $\mathrm{~J}, \mathrm{~K}, 6$ & Established \\
\hline Pуита ьопи & $\mathrm{C}$ & 1 & 1 & 0 & 0 & 0 & 1 & $\mathrm{~J}, \mathrm{~K}, 6$ & Established \\
\hline Styela canopus & $\mathrm{I}$ & 1 & 1 & 0 & 1 & 1 & 1 & $\mathrm{D}, \mathrm{H}, 6$ & Established \\
\hline Symplegma brakenbielmi & $\mathrm{I}$ & 1 & 1 & 0 & 1 & 1 & 1 & $\mathrm{D}, \mathrm{H}, 6$ & Established \\
\hline Symplegma sp. A & $\mathrm{C}$ & 1 & 1 & 0 & $?$ & 1 & 1 & $\mathrm{D}, 6$ & Established \\
\hline \multicolumn{10}{|l|}{ Osteichthyes } \\
\hline Gambusia affinis & I & 0 & 0 & 1 & 1 & 0 & 0 & $\mathrm{~A}, 2$ & Established \\
\hline Mugil cephalus & I & 0 & 0 & 0 & 0 & 0 & 0 & $\mathrm{~A}, 2$ & $?$ \\
\hline Neopomacentrus violascens & $\mathrm{I}$ & 0 & 1 & 0 & 0 & 0 & 1 & $\mathrm{~B}, 2$ & ? \\
\hline Omobranchus elongatus & $\mathrm{I}$ & 0 & 1 & 0 & 0 & 0 & 1 & $\mathrm{~B}, 2$ & $?$ \\
\hline Oreocbromus mosambicus & I & 0 & 0 & 1 & 0 & 0 & 0 & A, 2 & Established \\
\hline Parioglossus philippinus & I & 0 & 1 & 0 & 0 & 0 & 1 & $\mathrm{~B}, 2$ & $?$ \\
\hline
\end{tabular}

${ }^{a} \mathrm{C}$, cryptogenic; I, introduced.

${ }^{b}$ Is life style attached?

$c 1$ denotes yes, 0 denotes no.

${ }^{d}$ Occurrence in Apra Harbor.

$e$ Occurrence outside Apra Harbor in natural habitats.

$f$ Recorded outside Indo-West Pacific.

$g$ Encountered only on artificial substrata.

${ }^{b}$ Common on artificial substrata.

${ }^{i}$ Based on criteria listed in Table 2 (A-K) and following references: 1, Bailey-Brock (2002); 2, Eldredge (1994); 3, Eldredge and Paulay (1996); 4, Kelly et al. (2002); 5, Kirkendale and Calder (2002); 6, Lambert (2002a); 7, Smith (1987); 8, Southward et al. (1998).

${ }^{j}$ Current occurrence on Guam.

${ }^{k}$ Extra-Indo-West Pacific range is result of human transport into the Atlantic. 